\title{
Research on the Transformation of "Dual-Qualification" Teachers in the Local Application-Oriented Undergraduate Electrical Automation Field
}

\author{
Xiao-Yu WANG \\ Electronic Engineering College, XI'AN AERONAUTICAL UNIVERSITY, XI'AN China
}

Keywords: local application-oriented undergraduate; teachers in the field of electrical automation; "dual-qualification" teachers, transition.

\begin{abstract}
Guided by [2015] No.7 document and based on the problems like generallow teachers' quality, their inadequate professional experience, weak practical capability and incomplete incentive measures and assessment system existing in the transition of teachers in electrical automation field in local undergraduate institutions, this paper puts forward a series of measures like increasing personnel introduction and teacher trainings as well as perfecting teacher's incentives and assessment systems to finally realize transition of "dualqualification" teachers in the field of local application-oriented undergraduate electrical automation.
\end{abstract}

\section{Introduction}

In October 2015, the three ministries, Ministry of Education, the National Development and Reform Commission, and the Ministry of Finance, jointly issued Instructions on Guiding the General Undergraduate Colleges in Some Areas in Transforming to Applied Universities (National Development and Reform Commission of the Ministry of Education, [2015] No.7) [1], emphasizing that strengthening the ranks of "dual-qualification" teachers is one important step in local application-oriented transformation. In the light of the implementation of the national innovation-driven development strategy, the transition of local application-oriented undergraduate "dual-qualification" teachers can be taken as the most crucial part in college transition.

The western major developed countries started their practice exploration in applied universities earlier with Germany and Britain taking the lead. Germany's General Law on Higher Education issued in 1976 made it clear that professional education and vocational education are the core contents of higher education. At the same time, it stresses that professors in universities specific to applied technology should be equipped with qualities of "dule-qualification". Whereas in 1990s, the United Kingdom proposes that teachers in applied technology universities or colleges should mainly be technical personnel or senior management personnel [2].The successful development of applied technology-based universities in Germany and Britain as well as their experience in building teaching staff can be summarized as follows: the seamless connection among the guidance of national policies, the support of prefectural governments and industries, the participation and cooperation of industry and enterprises as well as the initiative transformation of schools according to local economic construction and industrial services. China's "dual-qualification" transformation in local application-oriented undergraduate colleges and universities can use it as reference.

During recent years, with the continuous promotion of the construction in local applicationoriented colleges and universities, many researchers in education have also actively had study in the construction of "dual-qualification" teachers. Zeng Yifan analyzed the significance, current situations and approaches of constructing "dual-qualification" teachers in local application-oriented undergraduate colleges[3]; Zhang Jie conducted a detailed exploration on the transformation of "dual-qualification" teachers in allusion to professional civil engineering 
teachers in local applied colleges[4]; Liu Yansong, from the perspective of teacher training, introduced his proposals on cultivating new talents in engineering majors in Shenyang districts[5].However, judging from the current situation of the newly-established transformations in local undergraduate colleges and universities, the weak construction of "dual-qualification" teachers has become a key factor restricting the transformation of university and the training of applied talents. Therefore, in order to meet the needs of the society for application-oriented talents, and to promote the development of local transformation and innovative connotation development, the local undergraduate colleges and universities actively explore the transformation of "dual-qulication" teachers for the purpose of serving the local economic construction and industry. Cultivating innovative, versatile, application-oriented and skilled talents in line with the educational plan are of the essence [67].

\section{Connotations of "Dual-Qualification" Teachers}

The definition of " dual-qualification " teachers can refer to Data Reporting Guidelines in Basic State Database of National Higher Education Teaching and Evaluation Center for Colleges and Universities (hereinafter referred to as reporting guidelines): firstly for professional teachers, they should hold intermediate or above teacher titles, and then meet any one of the following three conditions: a) the technical support - holding concessionary professional intermediate and above industry license with actual work experience, professional qualifications or professional skills assessment staff qualifications; b) the practical ability - in the past five years, having more than or equal to two years (which can be calculated) related work experience in enterprises, or participating in teacher professional skills training organized by the Ministry of Education and obtaining a certificate of completion, so as to fully guide students in professional practice and training activities; c) research results - directing or devoting a lot in two applied technology researches (or design and installation work of two on-campus practical teaching facilities and upgrading of technical level) in the past five years with their achievements having been used in enterprises or schools and reaching the advanced level in similar industries or schools[3] [8].Problems existing in transformations of Local application-oriented undergraduate "dualqualification" teachers specific to electrical automation

\section{The Overall Low Teachers' Quality}

National Development and Reform Commission of the Ministry of Education [2015] No. 7 document mentions that along with the gradual transformation of local undergraduate colleges to applied undergraduate colleges and orientation of running schools, problems like insufficient fulltime teachers and unreasonable structures have highlighted. In some places, undergraduate colleges and universities are newly-built ones or newly-upgraded ones, where the quantity of fulltime teachers is inadequate and the structure of teachers, age distribution and professional titles are irrational. On the other hand, there is still much room to optimize the structure of full-time teachers. From 2011 to 2014, the proportion of full-time teachers aged 35 and below continued to drop from $52.1 \%$ to $44.7 \%$, with young teachers still accounting for a large proportion, teachers with doctoral degree taking $8.4 \%$, and those with a bachelor's degree or non-degree occupying $1 / 3$. This phenomenon is particularly evident in private institutions. Compared with private colleges, the aged upgraded colleges and universities are better, such as teachers in Xi'an Institute of Aeronautical Automation, where reasonable structure of teacher distribution at various ages have formed with over 40-year-old teachers being transferred from the business or having years of engineering experience as a technical engineer, even though at the top of the faculty, there are fewer professors or professor-level faculty [9].

\section{Inadequate Professional Work Experience and Weak Practical Capability}

In April 8, 2016, China Education Daily (hereinafter referred to as the teaching quality test report) mentioned that compared with "985" and "211" research-based universities, local colleges and 
universities can only basically meet the teaching needs because of short construction time and insufficient number. The major of Electrical Automation emphasizes practical ability and standard professional practices, but the current status is that most professional teachers are undergraduate or postgraduate who directly enter the school without any engineering background. It is acceptable for them to teach students basic courses. However, for professional courses, especially those emphasizing the engineering applications, instruction can only base on the syllabus with weak theory linking with practice and unsatisfying evaluation results. For professional comprehensive experimental courses focusing on practical ability or project-based training courses, teachers should guide students to do more simple training projects. From the results of more professional evaluations of peers and experts, the teaching effects are not optimistic. During the process of guiding the graduation design, many topics selected by young teachers are obsolete and repeated, or more theoretical simulation ones. Adding inadequate teaching and practical resources, the hand-on ability of students has been weakened, let alone to train the innovative talents. Therefore, the objective of application-oriented personnel training can not be effectively achieved [10].

\section{Imperfect Incentive Measures}

Now frequently used incentive measures include spiritual incentives (such as honor, etc.) and material incentives, which are composed of direct compensation (like wage and bonuses) and indirect compensation (like working environment, training opportunities and promotion chances, etc.). Reasonable and effective incentives are of great significance in stimulating teachers' activeness, their self-growth planning and the reasonable structure of the teaching staff. Applied transformation in local undergraduate colleges and universities, during the external introduction or publicity, emphasizes the importance of "dual-qualification" teachers, but the incentive status is no different from that of other teachers. For spiritual incentives, more universities lay emphasis on scientific research but neglect teaching, which results in the status that during annual assessment or annual evaluation, those young and middle-aged teachers with academic titles are given the priority, while "dual-qualification" teachers' outstanding practical experience and rich engineering experience are often left out. Thus, the "dual-qualification" teachers lack sense of identity and belonging as well as enthusiasm to obtain the certificate of professional qualification and technical certificates. The work experience in enterprises and the industries are disregarded at the same time. For material incentives, the wage and bonuses of "dualqualification" teachers are the same with that of other teachers. Therefore, it fails to attract some high-end skilled personnel with rich engineering experience, restricting the channels of "dual-qualification" teachers. In addition, "dual-qualification" teachers in colleges and universities are also attracted by the high salaries in the off-campus companies or businesses, thus affecting the teachers' initiative, enthusiasm and teaching quality.

\section{Incomplete Evaluation System}

The assessment and evaluation policy is the "baton" for the university to mobilize the enthusiasm and initiative of teachers, and is also an integral part in constructing "dualqualification" teaching staff in applied transitional colleges and universities. However, at present, the evaluation system of "dual-qualification" teachers in these universities is not complete, lacking overall design for the assessment, evaluation and uniqueness compared with that of ordinary teachers. For example, in terms of workload assessment, there are no policy standards or guidance for the examination of "dual-qualification" teachers in both the teaching workload assessment and the research workload one. Just like what have been mentioned above, majors of electrical automation stress on practical ability and professional operating norms. Some teachers coming from enterprises or having years of engineering experience are able to continue to cooperate with external units or engineering parties on some projects after entering school. Unluckily, colleges and universities did not place particular emphasis on teachers with horizontal projects in the process of assessment, nor have flexible treatment of such situations, such as properly exemption in their scientific research assessment. In the 
aspect of job title assessment, all are the same with ordinary teachers, limiting the development of "dual-qualification" teachers for lacking specialization and pertinence [11].

\section{Research on "Dual-qualification" Transition in the Local Application-Oriented Undergraduate Electrical Automation}

With reference to the definition of "dual-qualification" teacher in Figure 1, taking National Development and Reform Commission of the Ministry of Education [2015] No. 7 document and the Teacher [2016] No. 7 document as the direction, based on the "National Education Plan", and combining the existing problems in "dual-qualification" transformation in local undergraduate electrical automation specialty, this part conducts study from the following aspects:

\section{Enhancing the Force of Introducing Talents}

As mentioned above, the structure of local application-oriented undergraduate teaching team is unreasonable with failure to effectively impact, help and drive young teachers as well as insufficient high-level teachers and innovation team. Therefore, appropriately lowering the requirements on the academic and scientific research in hiring industry professionals like talented professionals, as academic leader responsible for school-enterprise cooperation or professional chief in charge of discipline construction and revision of the training program of professional personnel according to requirements of professional ethics and positions on the workers in the production line (including the volitional quality, professional knowledge, professional skills, etc.). At the same time, in the light of the research direction of young teachers, short-term and long-term development planning should be made for them, so as to guide them to gradually participate in enterprise engineering projects, promote the combination between teachers and enterprise engineers and transform the business needs and teachers' achievement in enterprises into classroom teaching and practical teaching, to finally enhance the teaching quality of university teachers, research innovation and social service capacity. For example, several teachers in the Electrical Automation Department of Xi'an Aeronautical Institute combined the contents of the horizontal projects with the professions and interspersed the design requirements of the projects in specialized courses teaching. In the meanwhile, according to the enthusiasm and practical ability of the students, they selected the students to participate in the horizontal projects with the project subdivided into a number of sub-topics for students to take as graduate design topics. In addition, students were led to participate in engineering debugging in the site, which not only improved the students' practical ability, but also developed students' professional norms and employment ability, and finally allowed students to directly work without training period and the transitional examination period. In such ways, the application of personnel training objectives have been effectively achieved [1].

\section{Devoting Greater Efforts in Teacher Training}

National Education Plan" and National Development and Reform Commission of the Ministry of Education [2015] No. 7 document clearly proposes to strengthen the construction of "dualqualification" teachers, improve the training system, do well in training and planning and train the backbone of education and teaching as well as "dual-qualification" teachers. Focusing on "doublequalified" teacher construction through ways like training, academic exchange, project funding, cultivating "double-qualified teachers" relying on the relevant higher schools and large and medium-sized enterprises, teachers should be systematically selected and sent to enterprises for training, job attachment and practical training. It is necessary to build a"dual-qualification" teacher training base to perfect the system of teacher trainings in enterprises on a regular basis, and increase the proportion of professional teachers holding technical qualifications and professional qualification certificate. In Xi'an Aeronautical Institute, for the new teachers (based on whether or not having higher education qualification certificate), "twoeducation" and "two-examination" training modes are taken, that is, "education theory plus education skills plus mentoring examination plus supervision and examination". Only passing all training modules can teachers be allowed to teach on the podium. Whereas for 
the aged teachers, the assessment of "regular plus school/off-campus" approach is taken: young and middle-aged teachers and laboratory teachers under the age of 45 are required to practice in the enterprises every 3 years, or have attachment training with irregular training and evaluation in job skills in the school to motivate teachers to improve their practical abilities, and to carry out teaching methods such as practical engineering alternation, project-driven teaching, case study, small-topic study, teaching methods of simulation and production site combination. For the school's professional teachers in electrical automation major, vocational skill appraisal takes 4 years as the examination period to evaluate "dual-qualification" teachers with qualifications issued by national vocational skills appraisal center to make sure the validity of qualifications and successful transformation of “dual-qualification” teachers.

\section{Perfecting Teachers' Incentives}

Reasonable and effective incentives play a decisive role in "dual-qualification" planning and transformation. Firstly, the direct salaries (salaries and bonuses) should be increased. "dualqualification" teachers with outstanding contributions to professional construction and discipline construction should be granted special skills allowances or high-level honors. At the same time, they should be given priority to get training in order to attract and encourage more teachers to shift to "dual-qualification" teachers by opening up the channels. For indirect salaries (training opportunities, benefits, opportunities for promotion, etc.), flexible using policies and giving preferential policies are necessary. Such as, in the process of teacher recruitment or introduction, requirements on academic qualifications can be reduced with priority to hiring "dualqualification" teachers. At the stage of hiring and title assessment, the requirements on scientific research ability of "dual-qualification" teacher can be increased while the demands for "dualqualification" teachers to guide students to participate in various subject and skill competitions, awards and number of papers can be reduced, thus greatly promoting the transition and realization of "dual-qualification" teachers.

\section{Completing Teacher's Assessment System}

National Education Plan and National Development and Reform Commission of the Ministry of Education [2015] No. 7 document clearly states that perfecting teacher appraisal system is an urgent task to deepen the comprehensive reform of higher education at present and for the time to come. Local application-oriented colleges should design the examination content, assessment methods and evaluation methods in different levels and subjects, based on the job responsibilities and job characteristics of "dual-qualification" teachers, as well as different stages of careersthat teachers exist. For professional teachers in the field of electrical automation, during the scientific research assessment, those with the experience of horizontal projects can be flexibility handled, such as, to convert the horizontal projects into accounts receivable funding scores, discount part of the teaching workload and teaching scores with their research papers or scientific and technological achievements. Along with stressing on the characteristics of "dual-qualification" teachers, focuses should also be put on the assessment of "dual-qualification" teachers. In teacher assessment, the teacher professional development should be taken into the assessment system and according to the actual situation in the school, the specific requirements of the professional development of teachers should be refined. Establish teaching academic concepts, encourage teachers to carry out teaching reform and research and enhance teachers' academic development ability. For instance, teachers of Electrical Automation in Xi'an Aeronautical Institute, when National Education Plan" and National Development and Reform Commission of the Ministry of Education [2016] No. 7 document was just issued, he actively formulated respective fiveyear plans, on the basis of teacher planning, professional orientation, subject characteristics and school running objectives. Based on the local economic construction and industrial services, he devotes to cultivating the innovative, complex, applied, skilled personnel in line with national education plan [11]. 
In conclusion, the transformation of "dual-qualification" teachers in the local application of undergraduate electrical automation filed is a systematic project. First of all, it is necessary to clarify the meaning of the change and indicate the direction. Second, we must strengthen management and refine assessment to ensure the effectiveness and continuity of the transition. Finally, we need improve incentives and enhance teachers' initiative to achieve a win-win situation for higher education and personnel training.

\section{Acknowledgement}

This research was financially supported by Xi'an Aeronautical Institute Higher Education Project -Research "dual-qualification" teaching Team Construction in Application-oriented Undergraduate Electric Automation field (No. 2017GJ1008)

Fund Project: Xi'an Aeronautical Institute Higher Education Project -Research "dualqualification" teaching Team Construction in Application-oriented Undergraduate Electric Automation field (No. 2017GJ1008)

\section{References}

[1] The Ministry of Education, the National Development and Reform Commission, the Ministry of Finance Jointly Issued Instructions on Guiding the General Undergraduate Colleges in Some Areas in Transforming to Applied Universities [R], Beijing: National Development and Reform Commission of the Ministry of Education, [2015] No. 7, 2015-1023 .

[2] Liu Qitao. Exploration on the Course of "dual-qualification" Teaching Team Construction in University Specific to Applied Technology[J]. Science and Technology Enterprise, 2016, (17): 51-53.

[3] Zeng Yifan, Huang Rengang \&YAO Bo. Study on Construction Standard and Route of the "Dual-qualification" Teaching Staff in Local Applied Universities [J]. Heilongjiang Education, 2015, (12): 88-89.

[4] Zhang Jie \& Zhao Yongqing. Research on the Transformation of "Dualqualification" Teachers in the Field of Local Application-oriented Civil Engineering[J]. Journal of Combined College of Hunan University, 2016 (10): 99-100.

[5] Liu Yansong. Suggestions on the Training of Innovative Talents in Shenyang District- Construction of "dual-qualification" Teachers in Civil Aviation Institute of our University[R]. Shenyang: 3rd Annual Scientific Conference of Shenyang, 2016-09-27.

[6] Wang Runtong \& Puxue Tao. Research on The Transformation of Local Undergraduate Colleges and Universities and "dual-qualification" Teaching Team Construction[J]. Meitan Higher Education, 2016 (11): 71-75.

[7] Zhao Yezhu. The EU's Policies, Recommendations and Measures on Improving Teaching Quality[F]. Fudan Education Forum, 2015 (06): 101-106.

[8] Ministry of Education Teaching Evaluation Center for Higher Education. Data Reporting Guidelines in Basic State Database of National Higher Education Teaching and Evaluation Center for Colleges and Universities[K]. Ministry of Education Higher Education Teaching Evaluation Center, 2014 (8): 26.

[9] National Medium and Long-Term Education Reform and Development Plan [EB/ 
OL].Central Government Gateway,URL:http://www.gov.cn/jrzg/2010-07/29/Content_ 1667143.htm.

[10] Guiding Opinions of the Ministry of Education on Deepening the Reform of Teacher Assessment in Colleges and Universities, Teacher [2016] No. 7. Central Government Gateway, URL:http: // www.gov.cn/xinwen/2016-09/21/content_5110529.htm.

[11] Zhu Laibin. Explorations of Four-in-one Teacher Fostering Path in Local Undergraduate Colleges and Universities[J]. Fujian Normal University, Fuqing Branch, 2016, (06): 73-76. 